\title{
Geopolitics, geography and strategic history
}

Book

Published Version

Sloan, G. (2017) Geopolitics, geography and strategic history. Geopolitical Theory. Routledge, Abingdon, UK, pp272. ISBN 9780714653488 Available at https://centaur.reading.ac.uk/47837/

It is advisable to refer to the publisher's version if you intend to cite from the work. See Guidance on citing.

Publisher: Routledge

All outputs in CentAUR are protected by Intellectual Property Rights law, including copyright law. Copyright and IPR is retained by the creators or other copyright holders. Terms and conditions for use of this material are defined in the End User Agreement.

\section{www.reading.ac.uk/centaur}

\section{CentAUR}

Central Archive at the University of Reading

Reading's research outputs online 


\section{CHAPTER ONE}

\section{GEOPOLITICS: GEOGRAPHY, HISTORY AND STRATEGY: A TRINITY OF RELATIONSHIPS}

\section{Introduction}

This is a book about relationships and the puzzles they present. These two issues will be explored through a trinitarian structure. Understanding the manner in which geography, history and strategy interact and have produced political outcomes that have affected the security of states is the analytical objective. Initially it would appear that this relationship is self-evident given the fact that the configuration of terrain, changing technology and political preferences are widely recognized as being pivotal to all security arrangements. Deudney has pointed out, that there is a long history in attempting to develop explanatory power with respect to these variables: "geopolitical theorizing about the relationship between material contexts and security politics is also among the oldest and most central lines of argument in the 2,500 year project of Western political science."

\section{The Problem of Definition}

Despite this impressive intellectual lineage, which stretches back to antiquity, geopolitics in the early twenty first century has a three-fold problem. First there is the problem of definition. Every theory is generated for someone and for some reason. Geopolitical theory initially emerged -from Aristotle to Montesquieu and Machiavelli -- as a result of a naturalist intellectual impulse. In The Prince, Machiavelli suggested that mastery of geography is a key component to political survival: "He (the prince) should

\footnotetext{
${ }^{1}$ D. Deudney, “Geopolitics as Theory: Historical Security Materialism," European Journal of International Relations Vol 6, No 12000 p 78.
} 
learn the nature of sites, and recognise how mountains rise, how valleys open up, how plains lie, and understand the nature of marshes--and in this invest the greatest care...and the prince who lacks this skill lacks the first part of what a Captain must have."2

There are numerous contemporary definitions of geopolitics. Many focus on an appreciation of the development of modern economies, changes in transport and weapons technology, access to trade routes and resources. Aron has maintained that geopolitics "combines a geographical schematization of diplomatic - strategic relations with a geographiceconomic analysis of resources, with an interpretation of diplomatic attitudes as a result of the way of life and of the environment (sedentary, nomadic, agricultural, seafaring)." Gray has tried to disaggregate the concept to reveal its essential components: "Geopolitics is regarded here as a house with five rooms: geophysical resources; location; human resources--skills and culture; experience--the past, history, legends, myths; and mental cartography. These categories capture the sources of the political implications of geography."4 Sloan focuses on the way in which these components should function together to generate explanations: "Geopolitical theory is an attempt to draw attention to the importance of certain geographical patterns in political history. It is a theory of spatial relationships and historical causation. From it explanations have been deduced which suggest the contemporary and future political relevance of various geographical conceptualisations." Grygiel maintains that geopolitical theory has three constituent elements: lines of communication

\footnotetext{
${ }^{2}$ N. Machiavelli, The Prince (H.C. Mansfield Jr., Trans), Chicago: University of Chicago Press, 1985. p 59.

${ }^{3}$ R. Aron, Peace and War, London: Weidenfeld and Nicolson, 1966 p 191.

${ }^{4}$ C.S. Gray, Perspectives on Strategy, Oxford: Oxford University Press, 2013, p 125.

${ }^{5}$ G.R. Sloan, Geopolitics in United States Strategic Policy 1890-1987, Brighton: Wheatsheaf Books, 1988 p 8 .
} 
and their changing significance due to changes in transport and weapons technology, the location of sources of natural resources and the location of economic power. ${ }^{6}$ Furthermore, he has made an important claim about the nature of the geopolitical reality and its relationship to policy: "the first quality of geopolitics is its objectivity. By this I mean that geopolitics, or the geopolitical situation, exists independently of the motivations and power of states and is not contingent on the perceptions of strategists and politicians". 7

Applying a synthetic intellectual approach, all four definitions elucidate a common insight. Geopolitics is one of 'grand theories' of International Relations. It is illustrative of theorising in which interrelationships among a limited number of variables purport to explain a wide range of phenomena.

\section{The Problem of Usage and Currency}

The second problem is that of usage and currency. In terms of the modern literature of International Relations and Strategic Studies, it has become invisible. In one of the most important text books on International Relations, edited by Baylis and Smith, there is no reference at all to geography or geopolitics, and there is only one reference to strategic interaction. ${ }^{8}$ In one of the leading text books on International Relations theory, ${ }^{9}$ one that has gone through three editions, ${ }^{10}$ there is no reference to

\footnotetext{
${ }^{6}$ For a more detailed discussion of these three elements see J.J. Grygiel, Great Powers and Geopolitical Change, Baltimore: John Hopkins University Press, 2006, pp 26-36.

${ }^{7}$ J.J. Grygiel, Great Powers and Geopolitical Change, Baltimore: John Hopkins University Press, 2006, pp 24-25. Furthermore, he argues that a state has no capacity to change this geographic reality. Environmental changes take place over decades and a policy maker can only respond; he cannot control them.

${ }^{8}$ See Baylis and Smith (eds.), The Globalization of World Politics, Second Edition, Oxford: Oxford University Press, 2001, p 314.

${ }^{9}$ See Steans and Pettiford, An Introduction To International Relations Theory, Third Edition, Harlow: Pearson Education Limited, 2010.

${ }^{10}$ These editions were published in 2001.2005 and 2010.
} 
geography or geopolitics. In terms of the field of Strategic Studies the situation is little better: in the recent monograph by Friedman ${ }^{11}$ there is only a brief treatment of geopolitics; in the monographs by Heuser ${ }^{12}$ and Hill ${ }^{13}$ there is no explicit reference to geography or geopolitics and their relationship to strategy.

There are two notable exceptions to this intellectual black hole into which geography has fallen in the field of mainstream international relations theory. First is the work of Colin Gray, who has almost single-handedly addressed these relationships over nearly four decades of scholarship. In one of his most important works, he devotes a whole chapter to discussing 'Terrestrial Action.' ${ }^{14}$ The second is the work of Evans, who argued in 2001 that the international security system had become 'bifurcated': that is, a split had emerged between the dominant state paradigm and sub-state and transstate strata. The implication of this, it was claimed, has been a reduction in the relative importance of geography in the traditional strategic sense: it was no longer possible for a state to retreat behind physical borders. However, he did qualify what he meant by the 'relative decline' of geography: "In no sense does such a phrase imply 'the end of geography' in the same sense that Francis Fukuyma famously spoke of 'the end of history.' In terms of logistics, campaign planning and topographical analysis, geography remains fundamental to the art of war, while geopolitics remains an important component of statecraft." 15

\footnotetext{
${ }^{11}$ L Friedman .Strategy: A History, Oxford: Oxford University Press, 2015.p120-122.

${ }^{12}$ B, Heuser, The Evolution of Strategy, Cambridge: Cambridge University Press, 2010.

${ }^{13}$ C. Hill, Grand Strategies: Literature, Statecraft and World Order, New Haven: Yale University Press, 2010.

${ }_{15}^{14}$ See C.S. Gray, Modern Strategy, Oxford; Oxford University Press 1999 Chapter 8.

${ }^{15}$ M. Evans, From Kadesh to Kandahar, Military Theory and the Future of War, from Strategic Studies A Reader. T.G.Mahnken \& J.A. Maiolo (eds) London : Routledge 2014 p393-394.
} 
This lacuna flies in the face of the epistemological parameters of Strategic Studies. Wylie has argued that while strategy cannot lay claim to have the same degree of rigour as the physical sciences, it is an academic subject in which geographical considerations play a crucial role: "It can and should be an intellectual discipline of the highest order, and the strategist should prepare himself to manage ideas with precision and clarity and imagination in order that his manipulation of physical realities, the tools of war may rise above the plane of mediocrity." 16

This raises the question why has the usage of the geopolitical concept all but disappeared in the international relations literature? One reason has to do with the close association in the Anglo-American mind with the Nazi geopolitik. Hepple provides an assessment by illuminating the near terminal effect that the association of geopolitics with the German School of Geopolitics ${ }^{17}$ had: “ There does not seem to be any book title in English using the term geopolitics between the 1940s and Gray's Geopolitics of the Nuclear Era in 1977 (with the exception of Sen's Basic Principles of Geopolitics and History, published in India in 1975)" "18 The claim is also made that Henry Kissinger, in the late 1970s, was responsible for a revival of the term and gave important impetus to new directions in terms of writing on geopolitics. ${ }^{19}$ A second reason derives from the tendency in political science to rely on political variables when explaining political outcomes: Deudney has argued that: "In the human sciences, the dominant tendency was to look for the source of change in the development of human

\footnotetext{
${ }^{16}$ J.C. Wylie, Military Strategy :A General Theory of Power Control, Annapolis :UNIP, 1967 P?/ (check p number)

${ }^{17}$ For a detailed analysis of the origins and evolution of the German School of Geopolitics see G.R,Sloan, Geopolitics in United States Strategic Policy 1890-1987, Brighton: Wheatsheaf Books, 1988 p23-57.

${ }^{18} \mathrm{~L}$.W. Hepple, The revival of geopolitics, Political Geography Quarterly, Supplement to Vol 5, No 4,October 1986 p S22.

${ }^{19}$ Ibid p S25.
} 
institutions and culture rather than in the physical environment." ${ }^{20}$ Grygiel has summarized these two reasons as follows: "The vast majority of current international relations literature is characterized by the absence of geography. Although the perverted versions of geopolitics, notably Nazi geopolitik, are partly to blame for the current distain for geography, the main cause for the academic irrelevance of geography seems to be the tendency to explain political realities only through political variables."21

This decline in the usage of the concept has not been replicated in the currency of the term. In fact there exists an acute paradox in this respect. Geopolitics has never been more popular on the internet. A recent Google search for geopolitics yielded 5,570,000 results. A search for a more qualified geopolitical theory produced $3,610,000$ results. ${ }^{22}$ However, this widespread use has resulted in an etymological transformation: "the term 'geopolitics' has enjoyed a ghostly afterlife, becoming a ubiquitously used while being largely drained of substantive theoretical content, and is used in so many ways as to be meaningless without further specification. Most contemporary usages of the term geopolitics are casual synonyms for realist views of international strategic rivalry and interaction.",23

This 'ghostly afterlife' of a once vibrant intellectual concept has been further reinforced by the capture of the term by post- modern geographers. They added the adjective 'critical.' The result phrase, 'critical geopolitics,' suggests, according to Deundey, ${ }^{24}$ a strongly anti-materialistic vision, one that emphasizes the point that all geopolitical constructs serve an ideology

\footnotetext{
${ }^{20}$ D. Deudney, Geopolitics as Theory: Historical Security Materialism, European Journal of International Relations, Vol 6,No 12000 p83.

${ }^{21}$ J.J. Grygiel, Great Powers and Geopolitical Change ,Baltimore:Johns Hopkins University Press ,2006, p13.

${ }_{22}$ Accessed $15^{\text {th }}$ March 2015.

${ }^{23}$ Op cit p79.

${ }^{24}$ Op cit p79-80.
} 
while paying scant attention to how the strategic significance of geographic configurations change. Thus 'critical geopolitics' seeks to unmask how a geopolitical discourse reinforces power relationships, whether found in a specific text or in a general theory. ${ }^{25}$ It seeks "to define theoretically ideological clusters or 'discursive formations' which systematically organise knowledge and experience and repress alternatives through dominance." 26 It also claims a unique advantage and insight: "how social and political life is constructed through discourses. What is said or written by political elites-the whole community of government officials, political leaders, foreign policy experts and advisors-is a result of the unconscious adoption of rules of living, thinking, and speaking that are implicit in the texts, speeches, and documents. This group, on the other hand, is also considered to be the elite that guides the masses concerning how they should live". ${ }^{27}$ The unmasking of the hidden assumptions behind every geopolitical speech or text is a precondition for unravelling existing power structures and understanding geographic configurations. ${ }^{28}$

Classical geopolitics is interpreted as the antithesis of this approach: "geopolitics (classical) refers to a fixed and objective geography constraining and directing the activities of states... such as the disposition of states in relation to the distribution of the continents and oceans, or fixed

\footnotetext{
${ }^{25}$ There is an academic journal dedicated to this task, Geopolitics. It promotes what could be described as the political branch of geography. One of its constant themes is the emphasis on globalism. An example of this literature may be found here: C Flint ,The Geopolitics of Laughter and Forgetting :A World Systems Interpretations of the Post -Modern Geopolitical Condition, Geopolitics, Vol 6 ,No 3 ,Winter 2001.p1 -16

${ }^{26}$ W.Outhwaite ;T.Bottomore (eds),Dictionary of Twentieth Century Social Thought, Cambridge: Blackwell, 1993 p 161.

${ }^{27}$ S.R..Gokmen, Geopolitics and the Study of International Relations. PhD thesis, Middle East Technical University, August 2010 p79.

${ }^{28}$ Two examples of this literature are : M. W. Lewis and K. E Wigen, The Myth of the Continents: A Critique of Metageography (Berkeley: University of California Press, 1997) and J. M. Blaut, The Colonizer's Model of the World: Geographical Diffusionism and Eurocentric History (New York: The Guilford Press, 1993).
} 
processes of territorial-economic expansion relative to military strength, are seen as determining the strategic possibilities and the limits of particular states" ${ }^{29}$ Critical geopolitics makes a claim that is designed to change the meaning of the term: "by exposing the supposedly objective geographical element of geopolitics to be a contingent rather than absolute variable, critical geopolitics becomes the study of the power/knowledge networks that situate international politics". ${ }^{30}$ Black has responded to this argument by claiming: "critical geopolitics challenges our common understandings of definitions, categories and relationships, by replacing them with, in some cases, utopian wishful thinking, by political commitment instead of an objective appreciation of the causes of conflict, by foreshortened historical understandings and by a loss of clarity in communicating ideas", 31

\section{The Problem of Paradigm and Ideology}

The third problem can be described as a paradigmatic and/or an ideological one. Perhaps the most common mistaken assumption about geopolitical theory is its symbiotic relationship to the Realist approach. This maintains that all thinking about international relations should begin with the recognition of the primacy of power and that geographical factors are a vital part of the assessment of power. Realism has always claimed to provide a practical guide to statecraft. It is here that the nexus with geopolitics was identified: "Some basic IR theory texts argue that realism provides a guide based on the principles of realpolitik, for states to pursue their preservation and interests. When defined as such, it is no different from geopolitics. This point also tells us that the consistency between classical geopolitics and

\footnotetext{
${ }^{29}$ J. Agnew and S. Corbridge, Mastering Space, London: Routledge, 1995, p 3.

${ }^{30}$ J.P. Sharp, "Hegemony, Popular Culture and Geopolitics: the Reader's Digest and the Construction of Danger", Political Geography, Vol. 15, No. 67 (1996), p 559.

${ }^{31}$ J. Black, Geopolitics, London: Social Affairs Unit, 2009, p 3.
} 
realism turned out to be compulsory and inevitable."32 Both approaches are assumed to have common perspectives: practitioners and analysts in the field of international relations assume the international arena to be anarchical; states are viewed as the primary actors in that arena; the fundamental aim of states is the pursuit of power; their ultimate goal is the achievement of primacy and failing that, security. In short, the realist and the geopolitical analyst are assumed to share the same world view.

Deudney has contested this point of view. "Contrary to the contemporary identification of geopolitics with realism ... early geopolitical theory gave prominent attention to the relationships between material context and liberal forms of political associations ranging from city-state republics to large federal unions. ${ }^{, 33}$ Mackinder, one of the founders of classical geopolitical theory ${ }^{34}$ was an advocate of federalism in his seminal work Democratic Ideals and Reality ${ }^{35}$.He believed that in these political structures as many functions should be devolved to provinces, regions and communities as possible. This was better for people and their well being. In 1931 he applied this hypothesis to international relations: "Unless I am mistaken, it is the message of geography that international co-operation in any future that we need consider must be based on the federal idea. If our civilization is not to go down in blind internecine conflict, there must be a development of world planning out of regional planning, just as regional planning has come out of town planning." 36

\footnotetext{
${ }^{32}$ Ibid p177.

${ }^{33}$ D. Deudney, Geopolitics as Theory: Historical Security Materialism, European Journal of International Relations, Vol 6,No 12000 p78.

${ }^{34}$ Mackinder's ideas will be fully examined in Chapter Two.

${ }^{35}$ Chapter Seven of his book, which is titled the Freedom of Men, is devoted to this topic.

${ }^{36}$ H.J. Mackinder ,The Human Habitat, Records of the British Association of Advanced Science.1931, Quoted in. W. H. Parker: Geography as an Aid to Statecraft, Oxford :Clarendon Press .1982 p86.
} 
Not only is classical geopolitics not tethered to the administrative state - with its standing armies and its top-down fiscal apparatus - but it is also not to be identified exclusively with conservative political ideologies. In perhaps the most notable prediction to emerge out of an application of classical geopolitics, Collins distils its principles and hypotheses into a theory of explaining the stability of states and then applies that theory to the Soviet Union. In his magisterial essay, "The Future Decline of the Russian Empire," Collins predicted the breakdown of the Soviet Union due to the presence of unassimilated ethnic minorities that remained geographically concentrated in territories positioned along the rim of an empire dominated from Moscow by Russians. ${ }^{37}$ Collins, a conflict theorist and sociologist, was prompted to write this essay because he was concerned that the pressures the Reagan Administration applied to the Soviet Union could lead to a nuclear conflict. $^{38}$

Classical geopolitics is empirical in sprit; it recognizes the fact-based nature of geographic configurations, some of which may be overcome typically at great cost, economically or politically; but it is a grave mistake to believe that it is associated exclusively with any ideology or with any institutional framework for attaining a community's security.

\section{The Contribution of Geopolitics}

These three problems notwithstanding there is a continuing relevance of geopolitics to international relations. Geopolitics highlights the point that

\footnotetext{
${ }^{37}$ R. Collins, "Imperialism and Legitimacy: Weber's Theory of Politics," "Modern Technology and Geopolitics," and "The Future Decline of the Russian Empire," Weberian Sociological Theory (Cambridge: Cambridge University Press, 1986), pp. 145-166, 167-185, and 186-209.

${ }^{38}$ For further comment on Collins' prediction see L. Hochberg, The Language of National Insecurity: Prediction, Strategy, and Geopolitics," Advances in Competitiveness Research 2002 (10, 1); http://www.freepatentsonline.com/article/Advances-in-Competitiveness-Research/89491191.html, accessed September 8, 2015.
} 
securing political predominance is not merely a question of having power in the sense of the availability of natural resources, the acquisition of wealth or a capacity for projecting force, but it is also dependent on the configuration of the field within which that power is exercised. Over time, that field within which power is exercised may expand (or contract) given the changing nature of alliances, the emergence of new adversaries and enemies, shifts in where technological advances occur, mistaken policy decisions, and a number of other salient factors. Obviously, one goal of policy makers is to extend the geographic configuration over which power is exercised.

Geopolitical practice and the conceptualisations that it produces over time remain pertinent to the practice of international relations because "Geopolitical thinking is inherent to the very practice of foreign policy, though this is not always made explicit". ${ }^{39}$ Furthermore, it is from choices made by policy makers that political importance or relevance is attached to geographical configurations or locations. The geographical factors which influence politics are a product of policy makers selecting particular objectives and attempting to realise them by the conscious formulation strategies vis-à-vis potential or realized adversaries. In short a geographical perspective is inevitable if an international policy is to be formulated and successfully implemented in the teeth of inevitable opposition: "In nearly all international transactions involving some element of opposition, resistance, struggle or conflict, the factors of location, space and distance between the interacting parties have been significant variables. This significance is embodies in the maxim, 'power is local'. That is to say, political demands

\footnotetext{
${ }^{39}$ S.R. Gokmen, Geopolitics and the Study of International Relations, PhD Thesis, Middle East Technical University, August 2010 p192.
} 
are projected through space from one location to another." 40 As a result, the formulation of foreign policy should remain cartographically dependent. ${ }^{41}$

This the departure point for understanding the contribution of geopolitics, both as a tool of analysis and as a guide to practice. Since the industrial revolution, and the attendant technological revolutions in overland transport (via railway) and communication (via the telegraph), states have transformed the territorial jurisdiction through nationalizing the economy and centralizing political functions. ${ }^{42}$ Indeed, during the construction of railroads beyond the borders of a state and via favourable locations enabled imperial powers to attempt the assertion of economic hegemony, the projection of military force and the diffusion of values into previously isolated and/or contested regions. ${ }^{43}$

Perhaps the most significant instance a geopolitically-inspired reconfiguration of terrain in the modern period was the building of the "artificial strait" connecting the Atlantic with the Pacific Oceans across the Isthmus of Panama. Aguirre details the efforts by the foreign policy elite to secure the terrain through which the canal would be built, the construction of a doctrine of extra-territoriality to accommodate control, the geopolitical

\footnotetext{
${ }^{40} \mathrm{H}, \&$ M. Sprout, (to be finished)

${ }^{41}$ J. Hillen, "Foreign Policy by Map: What Geopolitics Is, and Why We Need It." National Review February 23, 2015; https://www.nationalreview.com/nrd/articles/413255/foreign-policy-map, accessed September 8, 2015.

${ }^{42}$ The literature on this point is extensive. Examples include E. Weber, Peasants into Frenchmen: The Modernization of Rural France, 1870-1914 (Stanford: Stanford University Press, 1976); D. E. Showalter; Railroads and Rifles: Soldiers, Technology and the Unification of Germany (Archon Books, 1975); S. G. Marks, Road to Power: The Trans-Siberian Railroad and the Colonization of Asian Russia, 1850-1917 (Ithaca: Cornell University Press, 1991).

${ }^{43}$ For instance, S. McMeekin, The Berlin-Baghdad Express: The Ottoman Empire and Germany's Bid for World Power (Cambridge: Belknap Press, 2010); D. Lewis, Iron Horse Imperialism: The Southern Pacific of Mexico, 1880-1951 (Tucson: University of Arizona Press, 2007); D. Devine, Slavery, Scandal, and Steel Rails: The 1854 Gadsden Purchase and the Building of the Second Transcontinental Railroad Across Arizona and New Mexico Twenty-Five Years (Lincoln, NE: iUniverse, 2004). And for more recent examples, see M. Z. Ispahani, Roads and Rivals: The Political Uses of Access in the Borderlands of Asia (Ithaca: Cornell University Press, 1989).
} 
consequences for the United States as it sought to become a nation with a two-ocean navy, and the current Panamanian repurposing of the Canal as a national asset over which they should have control. ${ }^{44}$ Once a reconfiguration of terrain occurs, policy makers must then face a new challenge. The approaches to the reconfigured location must be secured, thereby potentially setting in motion a further round of power projection into new regions. ${ }^{45}$

\section{The Place of Geopolitics: A Trinitarian Perspective}

Geopolitics should therefore be considered a synthetic field of study, one that addresses questions at the confluence of three disparate academic disciplines and their fundamental concerns: geography, strategic studies, and history. ${ }^{46}$

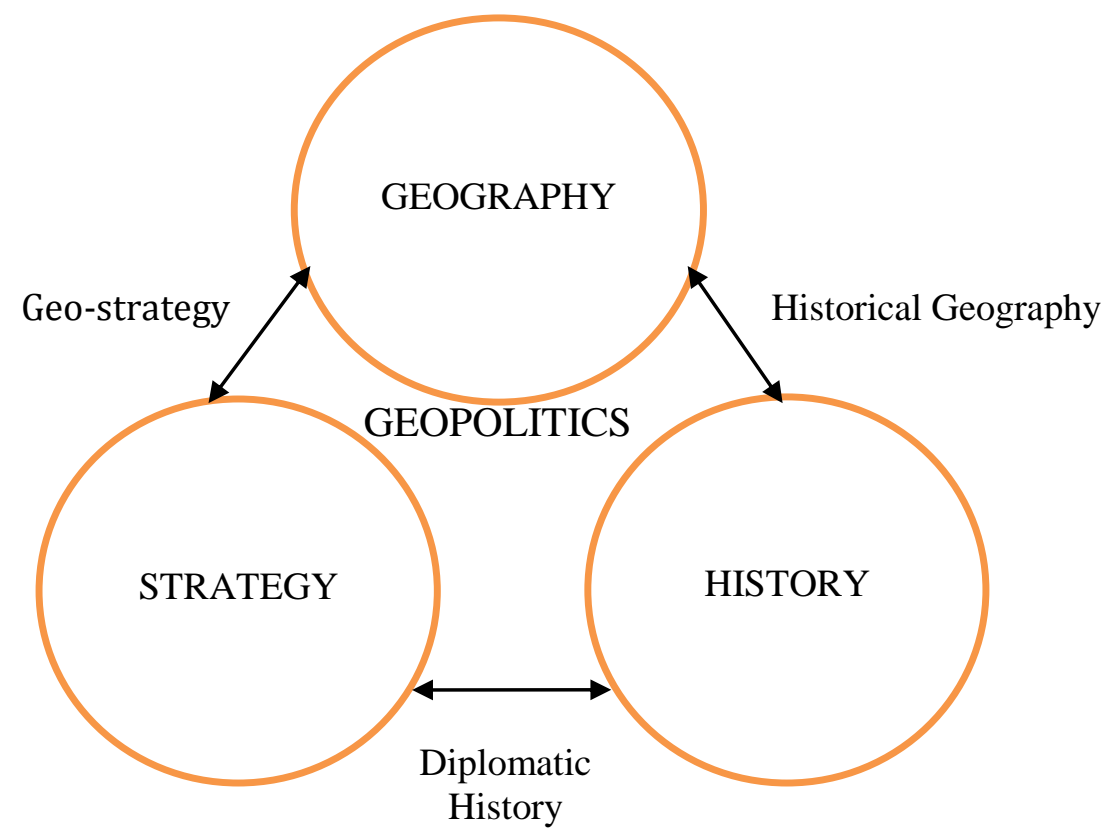

FIG 1.1

\footnotetext{
${ }^{44}$ R. Aguiree, The Panama Canal (Leiden: Martinus Nijhof, 2010).

${ }^{45}$ See Mackinder, Democratic Ideals and Reality, 89 for how Palestine flanks the Suez Canal.

${ }^{46}$ B. Haggman argued that "Geopolitics, both as Kjellen saw it and in its main Western i.e. Anglo-Saxon stream (Mackinder, Spykman et al) is a science which borders on history, geography and political science, but can also be regarded as an aid to all three. It is, to a great extent, a method of analysis more than a science in itself." in "Rudolf Kjellen and Modern Swedish Geopolitics, Geopolitics, Vol 3, No 2, Autumn 1998, p. 107.
} 


\section{Geography}

At its core, geography is the study of the "manifold features, physical and human, which diversify the earth's surface." ${ }^{.7}$ The physical configuration of the earth's surface, its mountains, plains, deserts, rivers, coastline, and seas, remains the stage on which the human drama that is politics is played out. Mountains and deserts were oftentimes barriers to human interaction whereas vast riverine plains opened before determined raiders, traders (in luxuries) and proselytizers. In the pre-industrial world, overland travel was relatively easily achieved, provided provisions could be seized or purchased en route; however, travel overseas remained monopolized by those who could afford it. In order to keep out or regulate the presence of undesired travellers, polities erected borders along defensible positions, ideally in mountainous terrain or along the banks of rivers. The formation of states, which may be defined as the monopolization of the legitimate use of force within a jurisdiction, necessitated the creation of borders, ideally defensible borders. Natural barriers, even when reinforced by defensive bulwarks and manned borders, have never achieved perfect security.

Travel across the surface of the earth is only one feature of human geography; transport is another. In the era prior to the mechanization of overland transport, the friction of terrain, even across the vast expanse of the Eurasian plains, limited the range of movement of bulky goods (even given the use of ox-drawn carts) to relatively short distances. Maritime transport (historically relying on access to free energy in the form of buoyancy and wind power) facilitated the movement of bulky goods (given a ship and a

\footnotetext{
${ }^{47}$ S. W. Wooldridge and W. G. East, The Spirit and Purpose of Geography (London: Hutchinson University Library, 1967 reprint), p. 11.
} 
crew that had to be fed) even over long distances, thereby enhancing an opportunity for regional specialization of production. Given the variability of the earth's surface, the opportunities and limitations for travel and transport enabled local populations to found polities that primarily operated through an overland exchange of communications among administrators and military officers, or through maritime exchanges of goods that generated great wealth. ${ }^{48}$ Ultimately the logistics underpinning these distinctive polities is grounded in physics and is the primary source the objectivity associated with the study of geography.

\section{Strategic Studies}

The field of strategic studies, in the modern context, examines the interactions between or among adversaries, engaged in conflict, potential or realized. A strategy is not merely a static plan of action, rather it is a dynamic awareness of one's goals, an evaluation of the efficacy of means, and an appreciation of consequences - given the fact that one's adversaries are also implementing their strategy to secure a desired, and perhaps even a mutually unattainable, outcome. As one adversary becomes aware of opponents and their capabilities, means may change, even goals may change as the consequences of seeking that which may be achieved only at an unacceptable cost.

Strategic studies, at the individual or institutional level, often focus on stratagems for attaining economic success, power, or sexual gratification. ${ }^{49}$

\footnotetext{
${ }^{48}$ E. W. Fox, History in Geographic Perspective: The Other France (New York: W. W. Norton, 1971)

49 For a comprehensive treatment, see the multivolume effort by R. Greene, The 48 Laws of Power, The Art of Seduction, and Mastery, New York: Penguin Books, 2000; 2001, and New York: Viking Penguin, 2012 , respectively. Greene is also the author of a book that is more exclusively macro in focus, The 33 Strategies of War, New York: Viking Penguin, 2006. Politicians often write about strategy. Consider D. Rumsfeld, Rumsfeld's Rules: Leadership Lessons in Business, Politics, War, and Life (New York: HarperCollinsPublishers, 2012). For a game theoretic approach to this subject see A. K. Dixit and B. J. Nalebuff, Thinking Strategically: The Competitive Edge in Business, Poltiics and Everyday Life (New
} 
Across time and space, adversarial relationships reveal five several essential processes. First, parties engaged in conflict seek to surprise their enemies through the use of deception and propaganda; second, they clandestinely gather sensitive information by deploying spies; third, in order to obtain a competitive edge, they develop new military or productive technologies; fourth, by engaging allies through diplomacy, they negotiate favourable shifts in the balance of power; and, fifth, they resort to violence or the threat of violence in order advance their interests or preserve their security. ${ }^{50}$ Adversarial relations are fraught with uncertainty; miscalculation and mistakes cannot be discounted in any analysis. Parties to a conflict rarely know for certain what an adversary's intentions, capabilities and tolerance for risk might be. Therefore, in the heat of battle, which is the singular moment of strategic action, chance and contingency may overcome meticulous planning; and these uncertainties are termed the fog of war. ${ }^{51}$

The process of making strategy is often elusive and hard to do: "strategy is neither policy nor armed combat; rather it is the bridge between them .The strategist can be thwarted if the military wages the wrong war well or the right war badly. Neither experts in politics and policy making nor experts in fighting need necessarily be experts in strategy. The strategist

\footnotetext{
York, W. W. Norton and Company, 1991.) W. Duggan draws on anecdotes from business to instruct readers on The Art of What Works: How Success Really Happens, New York: McGraw Hill, 2001. For an anthropologic approach to strategy, see F. G. Bailey: Stratagems and Spoils, Oxford: Basil Blackwell, 1980; Morality and Expediency: The Folklore of Academic Politics, London: Guildford and Worcester, 1977; Humbuggery and Manipulation: The Art of Leadership, Ithaca: Cornell University Press, 1988; and The Tactical Uses of Passion: An Essay on Power,_Reason, and Reality, Ithaca: Cornell University Press, 1983. Not for the faint of heart is H. von Senger's The Book of Stratagems: Tactics for Triumph and Survival (ed. and trans. by M. B. Gubitz), New York: Penguin Books, 1991.

${ }^{50}$ L. Freedman, Strategy, p. 3 mentions "deception and coalition formation, and the instrumental use of violence" as three "elementary features of human strategy that are common across time and space." To his list, we can add technological innovation and espionage. That these features of strategic thought and action are transhistorical and transcultural deserves further investigation.

${ }^{51}$ Clausewitz, On War, p. 101 describes war as occurring in a fog of uncertainty, where "A sensitive and discriminating judgment is called for; a skilled intelligence to scent out the truth."
} 
must relate military power (strategic effect) to the goals of policy...Strategy is difficult because, among other things, it is neither fish nor fowl. It is essentially different from military skill or political competence. ${ }^{, 52}$ It is through the use or the threat of the use of force that strategy has real purchase.

\section{History}

History, the third aspect of the Trinitarian relationship that constitutes geopolitics, is traditionally defined as what historians do : "Historical study is not the study of the past but the study of present traces of the past." By emphasizing the collation and assessment of surviving documents, historians, such as G. R. Elton, believed their field of study could be saved from preconceived notions. Furthermore, he argued that historians have three "habits [of mind] peculiar to history: its concern with events, its concern with change, and its concern with the particular." 53 For many traditionally minded historians, the "particulars" of the past are unique and the quest for understanding of the past is an appreciation of its difference from the present.

All these claims are now hotly contested. ${ }^{54}$ Pertaining to the documentary fixation of history, E. H. Carr ${ }^{55}$ has argued:

The fetishism ... of facts was completed and justified by a fetishism of documents. The documents were the Ark of the Covenant in the temple of facts. The reverent historian

\footnotetext{
${ }^{52}$ C. Gray, Why is Strategy Difficult, from Strategic Studies A Reader, (eds) T. G.Mahnken and J.A.Maiolo, London: Routledge, 2008 p 394.

${ }^{53}$ G. R. Elton, The Practice of History, New York: Thomas Y. Crowell Company, 1967, pp. 9 and 10.

${ }^{54}$ J. H. Hexter, Doing History, Bloomingdale: Indiana University Press, 1971; P. Gardiner, The Nature of Historical Explanation, Oxford: Oxford University Press, 1961; P. Burke, History \& Social Theory, Ithaca: Cornell University Press, 1992; E. H. Monkkonen (ed.), Engaging the Past: The Uses of History Across the Social Sciences, Durham: Duke University Press, 1994; T. J. McDonald, The Historic Turn in the Human Sciences, Ann Arbor: University of Michigan Press, 1996.

${ }^{55}$ E. H. Carr, What is History? New York: Random House, 1961, pp. 15-16.
} 
approached them with bowed head and spoke of them in awed tones. If you find it in the documents, it is so. But what, when we get down to it, do these documents - the decrees, the treaties, the rent-rolls, the blue books, the official correspondence, the private letters and diaries - tells us? No document can tell us more than what the author of the document thought - what he thought had happened, what he thought ought to happen or would happen, or perhaps only what he wanted others to think he thought, or even only what he himself thought he thought. None of this means anything until the historian has got to work on it and deciphered it. The writing of history has changed, too. ${ }^{56}$ No longer is there an exclusive emphasis on change and events arrayed in a narrative. Historians and social scientists ${ }^{57}$ have increasingly turned to writing about the "structures" of the past in which change, as their primary concern, has given way to an exploration of persistence. Some historians and social scientists have remained interested in change, but have abandoned the study of isolated, sharp, quick events in favour of a view of events embedded in long cycles. ${ }^{58}$

\footnotetext{
${ }^{56}$ J. R. Hall's Cultures of Inquiry: From Epistemology to Discourse in Sociohistorical Research, Cambridge: Cambridge University Press, 1999 is the best book on how the social sciences and history have sought to overcome the divide between generalizing and particularizing intellectual approaches. A useful reminder on the presence of exceptions in social scientific phenomena is to be found in J. H. Levine, Exceptions are the Rule: An Inquiry into Methods in the Social Sciences, Boulder: Westview, 1993.

${ }^{57}$ The list of contributors to this shift is overwhelming. A number have incorporated a geographic perspective in their writing. F. Braudel, The Mediterranean and the Mediterranean World in the Age of Philip II, Vols. I and II (trans. by S. Reynolds), New York: Harper \& Row, Publishers, 1973. . J. L. AbuLughod, Before European Hegemony: The World System A.D. 1250-1350, Oxford: Oxford University Press, 1989. E. Le Roy Ladurie, "History that Stands Still," The Mind and Method of the Historian (trans. by S. Reynolds and B. Reynolds), Chicago: Chicago University Press, 1981, pp. 1-27.

${ }^{58}$ I. Wallerstein, The Modern World-System: Vol. I, Capitalist Agriculture and The Origins of the European World-System in the Sixteenth Century, Vol. II, Mercantilism and the Consolidation of the European World-Economy, 1600-1750; Vol. III, The Second Era of the Great Expansion of the Capitalist World-Economy, 1730-1840s; New York: Academic Press, 1974, 1980, 1989 respectively. G. Modelski, Long Cycles in World Politics, Seattle: University of Washington Press, 1987. C. Earle, "The Periodic
} 
From the perspective of geopolitics, history should be understood as an appreciation and utilization of temporal frameworks that enable an observer to describe and analyse conflicts that have occurred in the past or break out in the present, and possibly even predict their future emergence and resolution. Whether the subject of geopolitics is the persistent geographic constraints on the options available to policy makers engaged in conflict, ${ }^{59}$ or the cyclical manner in which territorial integration and disintegration of dynastic empires occurs. ${ }^{60}$ Perhaps the most appropriate temporal approach to history, from the perspective of strategic studies, is the "analytical narrative," an approach ... [that] combines analytic tools ... with the narrative form...." This approach is simultaneously "analytic in that it extracts explicit and formal lines of reasoning, which facilitate both exposition and explanation." Why is the analytic narrative the desired approach? Because the strategic element essential to the study of geopolitics requires that, at some point, the analyst will attempt to engage the disparate intentions, capabilities - technological and otherwise - goals, and/or risk calculus pertaining to the consequences of the parties to the conflict. The great strengths of the analytic narrative approach are that it permits the analyst to tell stories of the back and forth of conflict, incorporate the assessments of the parties to the conflict-all from a robust appreciation of how strategy is related over time to geography.

\section{Connections}

\section{Geography and Strategy: Geo-strategy}

Structure of the American Past: Rhythms, Phases, and Geographic Conditions," Geographical Inquiry and American Historical Problems, Stanford: Stanford University Press, 1992, pp. 446-540.

${ }^{59}$ Braudel, The Mediterranean, pp.

${ }^{60}$ G. W. Skinner, "Presidential Address: The Structure of Chinese History," The Journal of Asian Studies, 44, 2 (Feb., 1985), pp. 271-292.

${ }^{61}$ R. H. Bates, A. Greif, M. Levi, J.-L. Rosenthal, and B. R Weingast,, Analytic Narratives, Princeton: Princeton University Press, 1998, p. 10. 
In order to capture the connection between geography and strategy, Grygiel coined the holistic expression, geo-strategy. By this he meant, "the geographic focus of a state's foreign policy, or where a state directs its power. It is a descriptive and not a normative concept because it does not propose where a state ought to direct its attention and project power." ${ }^{\prime 62}$ In the context of the projection of force, where the study of strategy and geography overlap, logistics, which is the "practical art of moving armies and keeping them supplied," ${ }^{, 63}$ stands out. A large armed force is essentially a city on the move; it must be fed, fuelled and provided with ammunition if it is to be effective on the battlefield. Thus, "[i]t follows that war, with its numerous tentacles, prefers to suck nourishment from main roads, populous towns, fertile valleys traversed by broad rivers, and buy coastal areas. All this will indicate that the general influence that questions of supply can exert on the form and direction of [military] operations, as well as the choice of a theater of war and the lines of communication.",64

Obviously, since Clausewitz wrote these words, weaker military adversaries have come to adopt guerrilla warfare; they disperse forces amongst the civilian population that simultaneously provisions and hides the warriors until their more conventional opponents are worn down by attackers whose status as civilians or warriors remains in doubt. ${ }^{65}$ Although

62 J.J. Grygiel, Great Powers and Geopolitical Change, Baltimore: John Hopkins University Press, 2006, p. 36.

${ }^{63}$ M. V. Creveld, Supplying War: Logistics from Wallenstein to Patton (Cambridge: Cambridge University Press, 1977), p. 1; see also the classic considerations by C. von Clausewitz, On War, ed. and trans. by Michael Howard and Perter Paret (Princeton: Princeton University Press, 1976) and A. H. Jomini, The Art of War (Philadelphia: J. B. Lippincott \& Co., 1862). J. Thompson, The Lifeblood of War: Logistics in Armed Conflict (Washington: Brassy's, 1991) and J. A. Lynn, ed., Feeding Mars: Logistics In Western Warfare From The Middle Ages To The Present (Boulder, CO; Westview Press, 1994) provide historic overviews. For an interesting case study drawn from ancient history, see D. W. Engles, Alexander the Great and the Logistics of the Macedonian Army (Berkeley, CA: University of California Press, 1978.)

${ }^{64}$ Clausewitz, On War, p. 338.

${ }^{65}$ R. Smith, War Amongst the People 
the routes over which the materiel must move to the site of battle may be direct and efficient or hidden and dispersed, move it must, often across terrain that is inhospitable, broken, and even contested. ${ }^{66}$ As Sun-Tzu stated, "One who does not know the topography of mountains and forests, ravines and defiles, wetlands and marshes cannot maneuver the army. One who does not employ local guides will not secure advantages of terrain." ${ }^{\circ 7}$

Sun Tzu's book of aphorisms, The Art of War (400 BC), makes the following point: "know the enemy, know yourself; your victory will never be endangered. Know the ground, know the weather; your victory will then be total". ${ }^{68}$ Strategy must take into account geography and an acute appreciation of the actual terrain across which an armed force has to fight can be critical to success. Sun Tzu developed a typology that would be of utility to the military commander. Geography not only shapes strategy but has a purchase on the operational and tactical levels of war: "warfare, the making of war, is first of all about the making the most of one's chances with the constraints imposed by nature." $" 69$

A successful military strategy has been accessed as having the following components: “clearly identifying political goals, assessing one’s comparative advantage relative to the enemy, calculating costs and benefits carefully, and examining the risks and rewards of alternating strategies." The purpose of military strategy is a singular one: "Strategy is designed to make war useable by the state, so it can, if need be, use force to fulfil its

\footnotetext{
${ }^{66}$ H. A. Winters with G. E. Galloway, Jr., W. J. Reynolds, and D. W. Rhyne, Battling the Elements: Weather and Terrain in the Conduct of War (Baltimore: Johns Hopkins University Press, 1998).

${ }^{67}$ Sun-Tzu's Art of War, trans. by R. D. Sawyer in The Seven Military Classics of Ancient China (Boulder, CO: Westview Press, 1993), p. 182.

${ }^{68}$ Sun Tzu, The Art of War, Oxford: Oxford University Press.1963 p129.

${ }^{69}$ D. Moran, "Geography and Strategy", from J. Baylis, James J. Witz and C.S. Gray (eds.), Strategy in the Contemporary World, Oxford: Oxford University Press, 2013, p116.

${ }^{70}$ T.G. Mahnken\& J.A. Maiolo, Strategic Studies A Reader ,London :Routledge.2014 p2.
} 
political objectives. ${ }^{, 71}$ Both these standard definitions fail to address relationship of geography with strategy. Indeed, Gray has argued that this relationship between geography and strategy has become largely invisible: "so habituated are we to the affirmations of the importance of geography for strategy, and so arguable are those claims, that the theory explaining why and how geography really counts is, in effect, missing in action", 72

Other analysts have suggested that a geographic perspective is essential to the realization of strategy. Aron, for instance, underlined the centrality of this relationship in the following way: "Strategy is movement; it is influenced by means of transport or communication. The utilisation of the terrain is essential to tactics." ${ }^{, 73}$ Owens has taken this point a step further by claiming that "by discerning broad geographical patterns, one may develop better strategic options by which a state can assert its place in the world". ${ }^{74}$ The state still has to ensure that the geographical structure of the field within which its power is exercised is as favourable as possible, while ensuring that its enemies or potential enemies are disadvantaged when operating within this same field.

Political objectives should dictate military strategy; and strategy should anticipate how force is successfully projected from one location to the next, each of which contains configurations of both physical and human geography. Proximate locations may often be perceived as roughly similar across a homogeneous region, but ultimately they are unique. The very fact of proximity may, for instance, lead to a local rivalry, which is all but

\footnotetext{
${ }^{71}$ H. Strachan, The Lost Meaning of Strategy, Survival, Vol 47,No 3,Autumn, 2005 p49.

${ }^{72}$ C.S. Gray, "Inescapable Geography", from C.S. Gray and G.R. Sloan (eds.), Geopolitics, Geography and Strategy, London: Frank Cass, 1999, p162.

${ }^{73}$ R. Aron, Peace and War, London: Weidenfeld and Nicolson ,1966 p181.

${ }^{74}$ M. T. Owens, "In Defence of Classical Geopolitics", Naval War College Review, Vol. 52, No. 4 (Autumn 1999), p63.
} 
invisible to an outsider. Therefore, for the policy-maker and the military commander, understanding how geography mediates a state's security is not a discretionary consideration. Sir Julian Corbett, writing in 1911, addressed this issue: "since men live upon the land and not upon the sea, great issues between nations at war have always been decided - except in the rarest cases - either by what your army can do against your enemy's territory and national life, or else by the fear of what the fleet makes it possible for your army to do. ${ }^{75}$ Beaufre drew attention to "material factors" in the different geo-strategic contexts of maritime and overland military activity: "the fact is that strategy must to a large extent be governed by material factors and the material factors characteristic of each field of activity differ, producing therefore a different chain of consequences applicable only to that field; for instance naval strategy has always been distinct from land strategy."

Geography, when it is manifested as geo-strategy, can best be understood in the context of a specific theatre of military operations. For the military commander, not every aspect of the fauna, flora, terrain and climate is of interest. Geographical features become more abstract, simplified and schematized in an effort to select for closer consideration only those geographical features that are relevant to the military objective. Cartographic design for military purposes reflects this consideration. In a chapter entitled "Terrain," Sun Tzu argued that every situation, and the options that it facilitated, should be subject to an analysis by the commander. The terrain and the way in which it may be used must be analyzed so that "clever positioning" could facilitate both tactical and operational advantage. The key relationship between the commander and these "positions" was the

\footnotetext{
75 J S Corbett, Some Principles of Maritime Strategy, London: Longmans, Green \& Co 1911, P12

${ }^{76}$ A. Beaufre, An Introduction to Strategy, London: Faber and Faber, 1965, p30.
} 
need to recognise and analyse whatever new situation he found himself in: "To estimate the enemy situation and to calculate distances and the degree of difficulty of the terrain so as to control victory are virtues of the superior general. He who fights with full knowledge of these factors is certain to win, he who does not will surely be defeated." 77 The 'positions' were abstract and relational concepts: accessible, entrapping, indecisive, constricted, Precipitous, and distant. In each, Sun Tzu outlined how the commander, must integrate these positions with his plans when conducting operations against an enemy.

In the following chapter, entitled 'The Nine Varieties of Ground,' Sun Tzu focused on how troops can be deployed and employed to the greatest tactical advantage on the terrain that they find themselves. Ground is classified as dispersive, frontier, key, communicating, focal, serious, difficult, encircled and death. The ability to calibrate the use of troops against this diverse typology is regarded by Sun Tzu as the commander's premier skill: "The tactical variations appropriate to the nine types of ground, the advantages of close or extended deployment, and the principles of human nature are matters the general must examine with the greatest care." $^{, 78}$

Today these geographical considerations fall under the military's term "combat intelligence": "leaders at all levels must therefore focus on those aspects that most directly affect their units' mission. Platoon leaders concentrate on streams, ditches, wood lines, fields and individual hills; division commanders are concerned with transportation networks, drainage patterns and hill systems. In either case, the leaders analyze the potential for

\footnotetext{
${ }^{77}$ Sun Tzu, The Art of War, Oxford: Oxford University Press 1963, P128

${ }^{78}$ Ibid P133
} 
cover and concealment, movement and obstacle effect, and observation and direct fire effect." ${ }^{79}$ Among the military, there is (and often unstated,) a powerful continuity between Sun Tzu's aphorisms and the modern approach to informed leadership in combat.

The relevance of geography to military operations has found expression in the classic writings of Carl Von Clausewitz. In On War, which was published in 1832, there was a chapter titled "The Elements of Strategy" wherein Clausewitz developed a typology of key variables that a military commander must consider before engaging in battle. They consisted of: psychological elements, including morale; military force, including its size, composition and organisation; geometry of the situation, including the relative positions and movements of forces and their relationships (distance, etc.) to obstacles, channels, objectives etc; terrain including mountains, rivers, woods and roads, all of which might influence military activities; and supply, including the amount given the size of the force, the means for securing it and the sources. It can be suggested that the relative importance, scale, and components of these factors may have changed, but they remain the basic elements of strategy. ${ }^{80}$

Where in these Clausewitzian elements of strategy is geography? To Clasusewitz, the geometry of operations, the environment of operations, and the sources and means of support are all geographic elements. This, in turn, raises the question: are these three geographic factors determinative of victory in land warfare? Clausewitz was careful to spell out the key relationship that pertained between these three geographical based factors

\footnotetext{
${ }^{79}$.E.J. Palka, Geographical Information in Military Planning, Military Review, Vol LXV111 No. 3 March 1988,p53.

${ }^{80}$ For an updated view of Clausewitz see: R Carlyle, Clausewitz's Contemporary Relevance, The Occasional, Number 16, Strategic and Combat Studies Institute, 1995.
} 
and the psychological: "the effects of physical and psychological factors form an organic whole which, unlike a metal alloy is inseparable by chemical processes. In formulating any rule concerning physical factors, the theorist must bear in mind the part that moral factors may play in it; otherwise he may be misled into making categorical statements that will be too timid and restricted, or else too sweeping and dogmatic." ${ }^{\prime 11}$ Clearly, for Clausewitz, the question of supply may limit the capacity of an army to engage an enemy effectively, nevertheless the paucity of supply is never the final word - an army that is highly motivated may secure victory despite these limitations.

Nor can we be certain that these three geographic factors discussed by Clausewitz are or have been equally useful in discussing the projection of naval and air power. Gray has argued "the geographical dimension of strategy is ubiquitous and permanent, yet varied in its specific influence upon particular conflicts at particular times." ${ }^{\prime 82}$ Peltier and Pearcy, in their 1966 classic, argued that the three geographical mediums of war - land sea and air - have each their own geography at the tactical and operational level, albeit one that is highly abstract and schematized. ${ }^{83}$ In terms of land warfare, they claimed that three factors are important: objectives, channels, and obstacles. There were two approaches to securing an objective: "separate into simple movements by a single force and multiple movements by divided forces. The simple movements may be conducted as a direct assault along a front, a penetration or a flank attack. The multiple movements may be in the form of diversionary action, convergent attack

\footnotetext{
${ }^{81}$ C Van Clausewitz, On War, Edited by M Howard \& P Paret, Princeton: Princeton University Press, 1976, P184

${ }^{82}$ C.S Gray, Modern Strategy Oxford :Oxford University Press,1999.p41.

${ }^{83}$ G Etzel Pearcy \& L C Peltier, Military Geography, New York: D /Van Nostrand, 1966
} 
including envelopment, or coordinated attack along a front. ${ }^{84}$ The ultimate military objective of land warfare consists of the exercise of control over a people; this goal does not apply for war conducted in the other two mediums, conflict on the sea or in the air. Therefore, in all three mediums of war, there is no such thing, in an absolute sense, as a common target or objective, the identification of which depends in each upon the larger plan of war.

Yet, the role of geography in land warfare depends greatly on the use to which both sides put contested terrain. According to Winters, "The record shows that the outcomes of many battles are decided as much by the loser's errors as the winner's astuteness. In that process geographical factors often have, in one way or another, a multiplying effect on a military operation. The continuing problem is that no one can precisely predict how the environment will influence the progress or outcome of the next battle. All one can be sure of is that in some way they will be formidable. Then, as unknowns appear, evolve and multiply, training, leadership, intelligence and innovation become increasingly important",

By way of contrast, the geography of warfare at sea has a focus on accessibility and mobility. Except in the case of amphibious assault, the objectives of sea warfare focus on the mobility of ships and fleets. Relative movement dominates the strategy of the sea. The speed of advance and radius of action have been the most important considerations. The post1945 technological addition to maritime combat has been the introduction of radar, the impact of which has altered the range of target identifications and the range of fire. The sustainability of movement at sea and related factors

\footnotetext{
${ }^{84} \mathrm{Ibid}, \mathrm{p} 53$.

${ }^{85}$ H. D Winters, Battling The Elements, P 269-270
} 
depends to a degree on the presence of land support and basing. In a geostrategic, sense the location of shore bases for resupply and repair facilities form the skeletal framework of a naval strategy. This raises the question of the extent to which advantage can be derived from a far flung system of operating naval bases and well-equipped dispersed fleets?

The geography of air warfare, while being unique in many respects, has elements which are redolent of both land and sea warfare. Its geographic dimension is concerned with basing to promote target identification and accessibility which requires the presence of air bases within the range of the relevant aircraft. Although the "area bombing" of the Second World War was the embryo of a strategic air force, the strategic function of air power came to prominence after 1945 with the advent of nuclear weapons. However, since the late 1980s, technological innovations have been so remarkable that they have imbued non-nuclear air power with a qualitative improvement in its ability to achieve theatre joint-force objectives directly. ${ }^{86}$

The key event prompting this re-evaluation of non-nuclear air power was the 1991 Persian Gulf War when the lethality and effectiveness of air weapons underwent the most dramatic transformation since the war in Vietnam: "The prompt attainment of allied air control over Iraq during the opening night of operation 'Desert Storm' and, more important, what that control allowed allied air assets to accomplish afterwards by way of enabling the rapid achievement of the coalitions objectives on the ground marked, in the view of many, the final coming of age of air power." $" 87$ The main change in recent military aviation technology has been the introduction of low

\footnotetext{
${ }^{86}$ B S Lambeth, Air Power, Space Power and Geography. From Geopolitics Geography and Strategy, eds. Colin Colin S Gray \& Geoffrey Sloan, London: Frank Cass, 1999,

${ }^{87}$ Ibid p 63.
} 
observability to enemy radar and infrared sensors, more commonly known as "stealth". The main implication of this technology has been the exponential growth of the two key elements of the geography of air warfare: target identification and accessibility. "The large force packages that the US Air Force and Navy routinely employed during the air war over North Vietnam offered the only way of ensuring that enough aircraft would make it to their assigned target to deliver the number of bombs needed to achieve the desired outcome. Today improved battle space awareness, heightened aircraft survivability, and increased weapons accuracy have made possible the effects of massing without having to mass. As a result, air power can produce effects that were previously unattainable." 88

If there is one independent variable that is frequently cited as having an impact on geography's pertinence to strategy, it is technology: "strategic geography actually changes over time. The primary cause has been technological change. ${ }^{89}$ The consequence has been that new strategic circumstances came into being that posed fresh strategic problems". 90 Thus states do not find themselves in a geographical strait-jacket; instead, locations rise and fall in the calculus of strategic significance with the introduction of new technologies; politicians and military commanders rely on technological change to alter geographical configurations in their favour

\footnotetext{
${ }^{88}$ Ibid P73

${ }^{89}$ For an introduction to the literature on military technology,See: J. U. Nef, War and Human Progress: An Essay on the Rise of Industrial Civilization, New York: W. W. Norton and Co., Inc., 1963; W. H. McNeill, The Pursuit of Power: Technology, Armed Force, and Society since A.D. 1000, Chicago: The University of Chicago Press, 1982; G. Parker, The Military Revolution: Military Innovation and the Rise of the West, 1500-1800, Cambridge: Cambridge University Press, 1988; M. van Creveld, Technology and War: From 2000 B. C. to the Present, New York: The Free Press, 1991; and J. Keegan, A History of Warfare, New York: Alfred Knopf, 1994; G. Friedman and M. Friedman, The Future of War: Power, Technology, and American World Dominance in the $21^{\text {st }}$ Century, New York: Crown Publishers, Inc., 1996; and M. Boot, War Made New: Technology, Warfare, and The Course of History 1500 to Today, New York: Gotham Books, 2008.

${ }^{90}$ J.Gooch ,History and the Nature of Strategy from The Past as Prologue, W.Murray and R.H.Simreich (eds),Cambridge: Cambridge University Press,2006,p141.
} 
and overcome those that seemed previously insuperable. ${ }^{91}$ However, the nature of this impact is not always straightforward: "at a time when precision-guided missiles can destroy a specific house hundreds of miles away, while leaving the adjacent one deliberately undamaged, small groups of turbaned irregulars can use tortuous features of an intricate mountain landscape to bedevil a superpower. In the latter case the revenge of geography is clear. But in the former case, too, those missiles have to be fired from somewhere, which requires a land or a sea base, thus bringing us back to geography, albeit to a less intimate and traditional kind". 92

In the final analysis, the relationship between geography and strategy is a complex one. The strategic thinker must ensure that the geographical structure of the field in which military power is exercised remains as favourable as possible while ensuring that enemies, potential or otherwise, are disadvantaged with respect to the geography in which they must operate. Gooch acknowledged this by citing Britain's historical experience: "while geography was fixed, strategic geography was not. British strategy makers faced many difficulties in that the significance, value, and strategic vulnerability or defensibility of particular parts of the globe varied depending on political configuration and the level of sophistication of local

\footnotetext{
${ }^{91}$ Culture is another factor influencing the relationship of strategy with geography. "Geography does not determine national strategic culture in some simple and mechanistic fashion, but the geographical circumstances of all kinds of a community cannot help but play a large role in the course of that community's historical experience. Strategic culture may be understood to be a set of socially transmitted attitudes, beliefs, and preferred procedures that members of a society learn, practice and teaches its new members. It is close to self-evident both that geographical factors (location, size and character of national territory, character of neighbours, and so forth) must permeate defence thinking, sometimes as an idée fixe. Although some of those geographical factors are subject to change and to a changing significance as technology and trade flows (inter alia) alter." ${ }^{91}$ See W. Murray\& A. Bernstein ,eds The Making of Strategy, Cambridge University Press, 1994 p 7-23, and p?for quote. For relevant examples: W. Murray, MacG. Knox, and A. Bernstein (eds.), The Making of Strategy: Rulers, States, and War (Cambridge: Cambridge University Press, 1994); G. Dijkink, National identity and Geopolitical Visions: Maps of Pride and Pain (London: Routledge, 1996); and, for a good overview of the subject, A. I. Johnston, "Thinking About Strategic Culture," International Security 19, 4 (Spring 1995), pp. 32-64.

${ }^{92}$ R.D. Kaplan, The Revenge of Geography, New York :Random House,2012p125-126.
} 
communications". 93 Though the technology may lead to a reassessment of the significance of a particular location, the security of communities, city states, nation states and empires is dependent on geography, or more specifically the scope and configuration of a field of military action. According to Gray: "Each geographically tailored form of military power contributes to the course and outcome of the war in the super-currency of strategic effect. This idea shapes the treatment of 'the grammar of strategy' across all distinctive geographical environments of conflict." 94 The impact of geography on strategy occurs whether in providing opportunities, in imposing limitations and in shaping the deployment and utilization of armed forces. Political goals in warfare must take these considerations into account for success to occur.

Politics, too, shapes the execution of strategy in the geographical context and there is a complexity to this process which is rarely articulated. ${ }^{95}$ Policy makers attach significance to certain locations based on strategy, but also on access to distant raw materials, the availability of far flung transport routes, and even attachments to sites of cultural import. ${ }^{96}$ The formation of strategy is a process that involves internal political influences and idiosyncrasies of individual behaviour as well as the process of external events and threats. ${ }^{97}$ The geographical factors which influence politics are a product of policy makers selecting particular objectives and attempting to realize them by the conscious formulation of strategies. A geographical perspective is required if policy is to be realised.

\footnotetext{
${ }^{93}$ J.Gooch ,The Weary Titan, Strategy and Policy in Great Britain,1890 -1918p282(check)

${ }_{95}^{94}$ C.S. Gray, Modern Strategy, Oxford :Oxford University Press,1999,p209.

${ }^{95}$ R. Smith, Utility of Force, p.?

${ }^{96}$ G. W. White, Nationalism and Territory: Constructing Group Identity in Southeastern Europe, New York: Rowman and Littlefield Publishers, 2000.

${ }^{97}$ W. Murray ,MacGregor Knox ,and A. Bernstein ,The Making of Strategy ,Cambridge: Cambridge University Press ,1994 p20.
} 
The relationship between geography and strategy can be distilled to the ability of senior commanders to collect, collate and develop an understanding of the geography, given the technology at hand, that can be used as a force multiplier when preparing plans for war and implementing the conduct of operations. ${ }^{98}$ Senior military commanders recognize that their efforts must be effective given that which is known, that which is unknown and, in the Rumsfeld's memorable phrase, the presence of "unknown unknowns." 99 Chief among the unknown unknowns is the ability of the adversary to surprise. O'Sullivan argued that: "Geography is fundamental to the calculations and judgements involved in mobility and surprise and they have a dual relationship. Movement creates surprise, and surprise generates movement. The possible configurations of this couple are constrained by the lie of the land and sea, the logistic possibilities and time." 100 Strategy depends on the conscious selection of certain geographical locations and the movements of forces, given the parameters of an overall plan, which must be flexible enough to encompass and respond to surprise, so that the possibility of defeating an enemy is enhanced or, in failing to achieve that ideal, survival of one's own country's is ensured.

\section{Geography and History: State Formation and Disintegration}

Historical geography addresses how geography has shaped the formation of cultures, economies, societies and polities. Thucydides, in the first book of The Peloponnesian War, encompassed geographic factors to explain the divergent paths Sparta and Athens took in becoming, respectively, the foremost military and naval powers in the era after the

\footnotetext{
${ }^{98}$ Within this context Peltier and Pearcy have identified six specific elements that make up the parameters of strategic geography :accessibility, mobility, visibility, communicability, availability, and vulnerability.

${ }^{99}$ D. Rumsfeld, Rumsfeld's Rules, p. 324.

${ }^{100}$ P.M. O'Sullivan, The Geography of War in the Post Cold War World, Ontario: Edwin Meller Press, 2001, p. 113.
} 
Persian War. ${ }^{101}$ Despite frequent attempts by Enlightenment thinkers, such as Montesquieu, severe doubts remained over reliance on climate and other environmental factors in explaining political culture and institutions. ${ }^{102}$ Hegel dissented from the use of geography as the determinant of political outcomes:

Nature should not be rated too high or too low; the mild Ionic sky certainly contributed much to the charm of the Homeric poems, yet this alone can produce no Homer. Nor does it continue to produce them; under Turkish government no bards have arisen. ${ }^{103}$

Nevertheless, social scientists have appreciated geographic factors as $a$ significant determinant, if rarely the determinant, of political development. ${ }^{104}$

In order to capture the nature of the political conflict within, beyond and across the borders of states, the Swedish political scientist, Rudolf Kjellen, ${ }^{105}$ coined the term "geopolitics," which was part of a typology designed to provide an understanding of how geography, which was but one element of an organic system of political science, would promote an understanding of the development and survival of a state. In his 1901 book

\footnotetext{
${ }^{101}$ R. B. Strassler (ed.), The Landmark Thucydides: A Comprehensive Guide to The Peloponnesian War, New York: Free Press, 1996, pp. 3-16.

${ }^{102}$ Baron de Montesquieu, The Spirit of the Laws, trans. by Thomas Nugent, New York: Hafner Publishing Company, 1949, pp. 221-27 and 320-21.

${ }^{103}$ G. W. F. Hegel, The Philosophy of History, trans. by J. Sibree, New York: Dover Publications, Inc. 1956, p. 80.

${ }^{104}$ Fox, History in Geographic Perspective, p. XYZ, disposes of "geographical determinism" by calling attention to the human ability to take geography into account when taking decisions, ignoring it at one's peril, successfully transform circumstances or developing new technologies to overcome challenges, or in making mistakes.

${ }^{105}$ He taught at the University of Gothenburg from 1891 until 1916. In 1917 he was appointed Professor of Political Science at Uppsala University.
} 
titled "Staten Som Lifsform,"106 he argued that it was possible to identify laws that governed state development. His aim was to parry a legalistic view that interpreted the state merely as the sum of the articles of its constitution and other basic laws. There were five important elements in Kjellen's system of political science; the first was "Geopolitik," which described the conditions and problems of the state which have their origins in its geographical characteristics, such as its position, configuration, and the nature of its territory. Secondly, there was "Ecopolitik" which looked at the economic foundations of a state; the third was "Demopolitik" which looked at ethnic composition and the population trends of a particular state; the fourth was "Sociopolitik" which advanced a sociological perspective on the state; and the final was "Cratpolitik" which emphasized the governmental institutions comprising the state's apparatus. Despite this promising early start, geopolitics languished for many years as social scientists turned their attention to universal propositions pertaining to international conflict and state formation.

In the aftermath of the Second World War social scientists focused on general theories of economic and political development. ${ }^{107}$ In the United States the Committee on Comparative Politics of the Social Science Research Council sponsored a series of volumes on political development, one of the most notable of which was Crises and Sequences in Political Development. This volume of collected essays addressed political and social development in Africa and elsewhere, sought to explain developmental outcomes as the result of how polities handled "the five

\footnotetext{
${ }^{106}$ This was subsequently republished in Germany in 1916 under the title Der Staatals Lebensform (The State as a Living Form)

${ }^{107}$ Geographers were not immune to this generalizing impulse. See R. Hartshorne, "The Functional Approach in Political Geography," Annals of the Association of American Geographers, Vol. 40 (1950), pp. 105 and 110 for his discussion of centrifugal and centripetal forces.
} 
crises of identity, legitimacy, participation, penetration and distribution ."108 National security was not explicitly mentioned as a crisis and, to the extent territorial issues were discussed, they were subsumed under the crisis of identity (societies identify with the territory occupied) or the crisis of penetration and government capacity (polities must cope with conquest or regional variation.) ${ }^{109}$

Four years after the publication of Crises and Sequences, an intellectual sea change occurred. ${ }^{110}$ Tilly edited volume 8 in the Studies in Political Development: The Formation of National States in Western Europe. By narrowing the scope to the European historical experience, the contributors prioritized the quest for national security, along with war making, policing, and military organizations in their analyses. ${ }^{111}$ In Stein Rokkan's essay, "Dimensions of State Formation and Nation-Building." a "cognitive map" of European development outlined titled "A Schematic Geopolitical Map of Europe." . He articulated a five-fold a typology of regimes (i.e., "Seaward Peripheries," "Seaward Empire-Nations," "CityState Consociations," "Landward Empire-Nations," and "Landward Peripheries." It was an attempt to classify the early-modern starting points for European polities-within an overarching geopolitical context of

\footnotetext{
${ }^{108}$ L. Binder, J. S. Coleman, et al, Crises and Sequences in Political Development, Studies in Political Development 7, Princeton: Princeton University Press, 1971, p. viii for quotes and pp. 112-114, 220-23 for discussion of territory in the context of the identity and penetration crises. An attempt was made to apply this approach to historical case studies by Raymond Grew (ed.) Crisis of political Development in Europe and the United States, Studies in Political Development 9, Princeton: Princeton University Press, 1978.

${ }^{109}$ J. LaPalombara, in his essay "Penetration: Crisis of Governmental Capacity," Crises and Sequences, p. 221 skirts how the quest for glory and security resulted in territorial expansion among the Enlightenment European monarchs, thusly: “ $\ldots$ in the administrative histories of several Western nation-states ... [t]he most fascinating among these are Brandenburg-Prussia and France ... the rulers of a particular polity sought to expand the geographic areas over which they could exercise control. What motivated these ambitions and attempted changes need not detain us here...."

${ }^{110}$ Fox, History in Geographic Perspective, 1971 and I. Wallerstein, The Modern World-System, I, 1974 both appeared. 
neighbouring regimes - as they began the respective processes of development or possible destruction. ${ }^{112}$

The question of how geography has influenced the formation and survival of states and other political institutions, such as feudal monarchies, city-states or multinational empires, or maritime empires is of paramount importance. The eternal and critical challenge that all statesmen face is how to ensure that their state as an organisation of land and people sustains itself as an organised unit. A key aspect of this is the need to ensure that the forces that bind disparate geographical regions and ethnic groups together are sustained. Furthermore, these forces need to hold at bay destructive forces, which are expressed politically, and could result in regional secession, revolution and state disintegration or conquest. ${ }^{113}$ Geographic factors and how they are understood can explain the survival or disintegration of states.

Geography is particularly useful in explaining how states survive. First, there is no such thing as a 'natural' state with 'natural' boundaries. Policy makers have to secure defensible borders, even at the risk of incorporating into their territorial jurisdiction irredentist populations. Calls for socialization, sometimes strenuous in nature, directed at these minority populations represent attempts to advance loyalty among the citizenry. In the contemporary period, ethnic cleansing has resulted from this impulse toward homogeneity. Political instability can arise from attempts of a particular ethnic group to give its folk traditions legal expression, thus creating a

\footnotetext{
${ }^{112}$ Stein Rokkan, "Dimensions of State Formation and Nation-Building: A Possible Paradigm for Research on Variations within Europe," Charles Tilly, ed., The Formation of National States in Western Europe, Studies in Political Development 8, Princeton: Princeton University Press, 1975, pp. 562-600 and 578-79 specifically for

${ }^{113}$ See T.F.Fazal, State Death in the International System, International Organization Vol 58 ,Spring 2004 ,pp311-344.
} 
power struggle over social prestige and the economic benefits. ${ }^{114}$ The boundaries of a state are rarely coterminous with the national society living within the jurisdiction of a state-let alone coterminous with a fully integrated national economy. ${ }^{115}$ Because borders were in doubt, the holder of the final and legitimate decision-making authority, i.e. sovereignty, remained contested until such time that "a more permanent political geography" was established. ${ }^{116}$

Second, because commerce may traverse the borders of the state, the impetus to control - abolish, regulate and tax - it is a significant impetus to the formation of the modern state. ${ }^{117}$ Feudal lords claimed the power to regulate control within their domains; however, would-be absolute monarchs of the early modern period sought to concentrate control over the economic life of the state by abolishing feudal privileges. Hirst has argued that a synthesis of territoriality and sovereignty bestowed a number of permanent tangible benefits on the institution of the state: most notably, the state becomes the "superior political agency that determines the role and powers of all subsidiary governments."118

Third, states may also promote the self-conscious realization that an ethnic group is in fact a community, with an attachment historically to a given territory, a distinctive culture, and a unique historical fate. Niebhur

\footnotetext{
${ }^{114}$ For one example in the early history of the United States see A. R. L. Cayton, Frontier Republic: Ideology and Politics in the Ohio Country, 1780-1825, Kent, OH: Kent State University Press, 1986.

${ }^{115}$ Consider: during the industrial revolution, iron and coal deposits may be found across a border in the territories of adversarial powers.

${ }^{116}$ R.J. Johnston, Geography and the State, London: Macmillan,1982 p41 and for the exclusivity of political control over a territory, see A. James, Sovereign Statehood, London: Allen \& Unwin ,1986 p13.

${ }^{117}$ An alternative perspective that sees the empire in terms of its relationship to geography as foreshadowing the modern state's control over the economy: "The state apparatus seems to have emerged as sedentary farming produced a surplus for exchange, allowing for trade, occupational specialization, and an increasing stratification of society. Evidence from the Middle East, the Indus basin, and the Nile valley suggests the growth of trade and specialization stimulated agglomeration in specialized communities, the early towns.” R.E.H. Mellor, Nation, State, And Territory, London: Routledge,1989 p41-42.

${ }^{118}$ P Hirst, War and Power in the $21^{\text {st }}$ Century, London: Polity Press, 2001, p45.
} 
made a crucial insight to the degree of artifice, which can vary from state to state, that is required to hold the nation state together: "it was tempting to forget that communities are composed of organic and of contrived forms of cohesion. In civilised societies both are necessary. The necessity for both forms is constant, but the proportion between them is variable according to the culture, the degree of education in a nation and the intensity of the means of communication". ${ }^{119}$ To some extent, all national communities were "imagined communities," either intellectuals invented such communities or they systematized and glorified ethnic traditions as the essence of a new nation. ${ }^{120}$ In either event, standards-laws, regulations, and norms-were imposed.

Although the historical circumstances of every state has been different, in terms of their development, every nation state, in Europe at least, had a common starting point. The process began by the expansion of what Pounds and Ball called "core-areas" [See figure 1.2]. ${ }^{121}$ These core areas had three salient qualities: first, they had to be able to defend themselves from attack and encroachment; secondly, they had to be capable of generating a surplus income to pay for the armed forces that could, if required, facilitate further expansion; thirdly, they had to have the capability to participate in long-distance commerce, which was usually river borne, to obtain materials which were not available locally. To these three, Hechter suggests a fourth: a more or less homogeneous ethnic group that dominated the area that comes to be identified with the state: Castile in Spain, Île de France in France, the Home Counties in England, etc. "Each of these small

\footnotetext{
${ }^{119}$ R. Niebuhr, Nations and Empires, London: Faber and Faber, 1959, p. 260

${ }^{120}$ B. Anderson, Imagined Communities: Reflections on the Origin and Spread of Nationalism, London: Verso, 2006.

${ }^{121}$ N.J.G.Pounds \&S.S.Ball, Core Areas and the Development of the European States System ,Annals of the Association of American Geographers Vol 54 ,No 1,1964.
} 
areas had, to varying degrees, distinct cultural practices from those of outlying, peripheral, areas.", "122 These "core-areas" were all well developed by the Treaty of Westphalia in 1648 .

In comparison to these core areas, the peripheral, outlying areas were relatively isolated from one another and from the dynamism characteristic of the core area. For example in south western region of medieval France, there was a pattern of settlements called 'bastides'. These fortified settlements in rural habitats were located in the contested zone between the Kings of England whose rule extended south to Aquitaine, which was part of the Angevin Empire, and the lands ruled by the Count of Toulouse. Between 1222 and 1373 over five hundred 'bastides' were built and they enabled the local population to benefit from the important economic, political and strategic functions these constructions performed. In this contested zone, local populations, occupying diverse pieces of land, had the political resources to declare or withhold political allegiance. ${ }^{123}$

The importance of core areas in the European state system was enhanced by two related developments that took place in the $16^{\text {th }}$ and $17^{\text {th }}$ centuries. First, the growth of central authority within medieval kingdoms gradually succeeded in undermining the autonomy of feudal units within their domain. Secondly, the central authority, usually the king, managed to seal their state against the incursions of outside authorities. It was that process that led to the modern concept of sovereignty: "[the ruler] has the power to constrain his subjects, while not being so constrainable by superior power. The decisive criterion thus is actual control of one's 'estate' by

\footnotetext{
${ }^{122}$ M. Hechter, Internal Colonialism: The Celtic Fringe in British National Development, Transaction Publishers, 1998, 2nd ed., p. 5. See also N. J. G. Pounds and S. Bell for a map of the "also rans" among the core areas that failed to construct or preserve an autonomous state in "Core Areas and the Development of the European State System," Annals of the Association of American Geographers, 54, 1 (1964), pp. 24-40.

${ }^{123}$ See G. Bernard, The Bastides of South-West France, Toulouse: Diagram Edit Eur, 1991.
} 
one's military power, which excludes any power within and without.",124 These processes, internal directed against feudal competitors and external against emperors and popes, marked the end of the medieval structure.

These processes were not peaceful. "The 'fixing' of national spaces on the European map took place in the midst of widespread violence and warfare, particularly during the Reformation, the Counter-Reformation and the Thirty Years War, a conflict that claimed up to 30 per cent of the population in parts of central Europe." ${ }^{\prime 25}$ European states were in a "competitive geopolitical environment" 126 and thus policy makers had a powerful motivation to build administrative infrastructure enabling the extraction of revenue from the ruled societies in order to pay for military campaigns and standing armies. The territorial state became the dominant political form in Europe because it : "triumphed over other possible forms (empire, city-state, lordship) because of the superior fighting ability which it derived from access to both urban capital and coercive authority over peasant taxpayers and army recruits." 127

The ambiguity of border areas, the mutability of commerce, and the non linear progress for national community meant that the formation and consolidation of the modern state took much longer ${ }^{128}$ than is normally supposed. Although the inception of the modern state is often dated from the Treaty of Westphalia in 1648, its consolidation, according to Smith, in the practice international politics is relatively recent: "the First World War

\footnotetext{
${ }^{124}$ J.H. Herz, "Rise and Demise of the Territorial State", World Politics, Vol. 9 (1957), p479.

${ }^{125}$ M. Heffernan, The Making of Europe Geography and Geopolitics, London: Arnold ,1998 p17.

${ }^{126}$ G. Gill, The Nature and Development of the Modern State, Basingstoke: Palgrave Macmillian,2003 p186.

${ }^{127}$ T, Ertman ,Birth of the Leviathan, Cambridge: Cambridge University Press, 1997 p4.

128 "Instead of scattered islands of political power, each almost isolated from the other, there was a solid block of territory in which one ruler had final authority. It took centuries to attain this result." J.R.Strayer, On The Medieval Origins of The Modern State, Princeton: Princeton University Press ,1970 , p. 31.
} 
achieved a kind of final geopolitical shakeout, establishing a discrete system of national territories throughout Europe. It was final not in the sense that no further geopolitical change occurred; clearly it did. Rather the form of the territorial system of nation states-decades, even centuries, in evolution truly came to fruition only after World War One." 129 The articulation of an international norm was required, one that suggested that each nation should exercise "self-determination" through acquiring an exclusive territory and a state apparatus. Such a norm did not abolish conflicts between states, but provided a new rationale for territorial redistribution through subversion and/or conquest. ${ }^{130}$

Beyond the European experience, the failure of modern state formation is oftentimes attributed to the artificiality of the borders imposed on African and Asian colonies by the maritime European powers, with the incorporation into these territories of disparate ethnic groups. Yet, the European experience also required rulers to deal with disparate ethnic groups residing in territories incorporated behind artificial borders.

Nevertheless, the relationship between the core areas and their respective peripheries has allegedly gained little traction in the formation of states beyond Europe. Acemoglu and Robinson have argued that these coreperiphery processes generate little explanatory power: "Geographic factors are unhelpful for explaining not only the difference we see across various parts of the world today but also why many nations such as Japan or China

\footnotetext{
${ }^{129}$ N. Smith, American Empire: Roosevelt's Geographer and the Prelude to Globalization, Berkeley: University of California Press, 2003, p. 118.

${ }^{130}$ J. D. Hardy and L. J. Hochberg, "The Ukraine Crisis, Part II: Borderland" Mackinder Forum, April 9, 2014: http://www.mackinderforum.org/commentaries/the-ukrainian-crisis-part-ii, accessed September 30, 2015.
} 
stagnate for long periods and then start a rapid growth process." ${ }^{\prime 131}$ What seems to have been absent in much of the rest of the world is the reinforcing processes of a sovereign territorial state penetrating the society, a dynamic market economy which facilitated the goal of a self-perpetuating growth, and a strenuous geopolitical environment that spurred economic and military competition.

In much of the Middle East states and the indigenous Asian empires this dynamic was attenuated: they were largely agrarian in focus and "did not penetrate the society very effectively and certainly not as deeply as the states of the West..." Second, "the absence of geopolitical competition for Asia empires robbed them of the impetus to rationalize structures at home and encourage innovation in technological development ... the Mughal, Caliphate and Ottoman empires did not penetrate deeply into the societies over which they ruled. The linkages between centre and region were weak and extended, with central power at best exercised directly only on an episodic basis." $" 132$ In Africa the formation of nation states was different again. Here was the product of a specific colonial process whereby the

${ }^{131}$ D. Acemoglu \& J.A.Robinson, Why Nations Fail, London: Profile Books, 2013, p. 56 for quote. These authors also endorse (on p. 51) a mono- causal economic explanation that sets geography aside: "The great inequality of the modern world that emerged in the nineteenth century was caused by the uneven dissemination of industrial technologies and manufacturing production. It was not caused by divergence in agriculture performance." Darwin has argued that there were also cultural influences at work: "Absolute loyalty to a territorial state and its ruler conflicted with notions of an Islamic community of believers- the umma -and the autonomous authority of those who interpreted the Korean and the sharia." J. Darwin, After Tamerlane, London: Penguin Books, 2008, p. 498.

However, in Europe there also was an unequal access to technology among the various rulers which spurred mercantilist and other controls over economic development. The contest between monarch and pope for the allegiance of Christians in Europe was resolved in favour of the monarchs. It is not clear why unequal access to technology or the quest for universalistic cultural factors embedded in powerful, trans-national institutions should operate differently in Africa and Asia-and not be susceptible to a geographic analysis. There is no guarantee that the outcomes will be the same, but perhaps the fundamental point is that the newly independent former colonies and protectorates of the European powers have not had enough time to redraw their borders. If the European experience is a useful temporal yard stick against which state-formation might be measured, the sixty years since the end of World War II and the beginning of decolonization is simply not enough time for the relevant processes to have occurred.

${ }^{132}$ G. Gill, The Nature and Development of the Modern State, Basingstoke: Palgrave Macmilian ,2003 p186. 
maritime European powers leveraged a clear advantage from their ability to use and apply a specific number of technologies: "The steamship and the railway were the battering rams with European traders could break the monopolies that the African coastal elites and their inland allies had tried to maintain over their commercial hinterlands." 133 China was a product of yet another unique process. At times, there were periods of dynamism; yet its constituent elements were different from the competitive geopolitical environment of the European states: "The Chinese Empire, relying upon a highly developed bureaucracy drawn from the society generally and held together by the discipline imposed by ideology, the Chinese state during its periods of strength probably exercised at least as much power over many of its regions as did any large European state." ${ }^{134}$ China perceived itself culturally as the 'middle kingdom,' with a periphery of weaker and smaller states all of which were expected to acknowledge Chinese superiority and offer tribute. ${ }^{135}$

Today the nation state remains pivotal: it is still the basic unit of international relations and it still dominates the state's jurisdiction, though both have been significantly challenged since the end of the Cold War. One thing is certain: the geography of the state is not a static phenomenon; it has undergone transformations in the past, is undergoing significant ones now, and will do so in the future. In the immediate aftermath of the Cold War,

\footnotetext{
${ }^{133}$ J. Darwin, After Tamerlane, London :Penguin Books,2008 p305.

${ }^{134}$ G.Gill, The Nature and Development of the Modern State, Basingstoke: Palgrave Macmillan,2003,p186.

${ }^{135}$ Historical sociologists have, by and large, been responsible for the literature on state-formation and revolution: B. Moore, Jr., Social Origins of Dictatorship and Democracy: Lord and Peasant in the Making of the Modern World, Boston: Beacon Press, 1966; C. Tilly, ed., The Formation of National States in Western Europe, 1975; R. Bendix, Kings or People: Power and the Mandate to Rule, Berkeley: University of California Press, 1978; T. Skocpol, States and Social Revolutions: A Comparative Analysis of France, Russia, and China, Cambridge: Cambridge University Press, 1979; J. A. Goldstone, Revolution and Rebellion in the Early Modern World, Berkeley: University of California Press, 1991. Mainstream authors in international relations in general have not recognized how these processes of state formation impinge on the international system.
} 
political scientists proclaimed the end of the state. Globalization had defeated geopolitical considerations. The most important challenge to the state and the territory over which it was sovereign was the advent of "a process in which capital moves on the globe in search of profit with no constraints on its activities. As a result of this process national states are weakened and deprived of regulatory capacity". ${ }^{136}$ Given the impact of globalization, the borders of the state and the international arena beyond have become more porous: "as sovereignty is weakened, whether by people identifying with some 'world-culture' other than a national one, or through the increased activities of multinationals operating as economic units within the open lattice-work of nation-states, the power of the nation-state to determine the futures of its citizens is slackened too. However, the weakening of the power of the nation-state within its own borders tends to unleash countervailing forces to the global ones in the form of intensely nationalist sentiments." 137 "Globalisation" in its economic (movement of capital and emergence of free markets), cultural (challenges to traditional values via new forms of communication), political (the irresistible victory of liberal-democracies) and demographic (the welcoming of immigration, including illegal immigrants) manifestations remains vigorously contested. ${ }^{138}$ Advocates and detractors mobilize cosmopolitan versus national values in their various defences and attacks on this process. ${ }^{139}$

\footnotetext{
${ }^{136}$ N. Kliot and D. Newman, Geopolitics at the End of the Twentieth Century, London: Frank Cass, 2000, p 2.

${ }^{137}$ S. Waterman, "Partition, Secession, Recession and Peace in our Time", Geojournal, Vol. 39, 1996, p. 351.

${ }^{138}$ From the end of the First World War to the end of the Cold War the line between the state and the international system in which it operated was assumed to constitute two separate, hermetically sealed, entities. This binary line and the assumptions that went with it dissolved in a manner that few policy makers or academic writers have anticipated: "That the high politics of diplomacy and strategic affairs could and should be separated from the low politics of domestic politics and transnational relations is no longer valid. Ethnicity, with its ability to influence state behaviour both domestically and internationally perhaps most obviously through secessionist and irredentist movements in a number of critically important
} 
Furthermore, the process of globalisation has been interpreted as removing two of the most important rationales for the existence of nation state: the ability to engage in self-defence and the competency to wage war. Ignatieff has summarised the enduring salience of these two qualities:

a new interdependence might be emerging in the economic realm, but there is no discernible alternative to the nation state as the chief provider of foreign and domestic security for most human populations. Commerce may be borderless, but human beings cannot be. They need secure territories to live in, and these can only be provided by states with monopolies over the legitimate use of force. It is difficult to imagine any global, regional or continental body replacing the state in these functions, because these bodies lack the democratic legitimacy if citizens are to be sent to kill and to die. ${ }^{140}$

In the aftermath of the attacks on $11^{\text {th }}$ September 2001, Professor John Gray endorsed Ignatieff's views by sounding the death knell of this era of unrestrained globalization: "the conventional view of globalisation as an irresistible historical trend has been shattered. We are back on the classical terrain of history, where war is waged not over ideologies, but over religion, ethnicity, territory and the control of natural resources."141

The implications of this argument should not be ignored. The independent states that exist today are products of very different processes of

regions -is now the very essence of high politics." S.R. Gokmen ,Geopolitics and the Study of International Relations, PhD thesis, Middle East Technical University ,August 2010, .p. 174-175.

${ }^{139}$ The literature on this subject has been vast as it has been the varied. For example: E.N. Luttwak, "From Geopolitics to Geo-Economics," National Interest, Vol. 201, (1990), pp17-24; R. Boyer and D. Drache (eds.), States Against Markets: The Limits of Globalisation, London: Routledge, 1996; and K. Ohmae, The End of the Nation State, London: Harper and Collins, 1995.

${ }^{140}$ M Ignatieff, Virtual War, London: Vintage, 2001, p176.

${ }^{141}$ J. Gray, "The Era of Globalisation is Over", New Statesman, (24 ${ }^{\text {th }}$ September 2001), p25. 
state formation; however, all have a relationship to the territory that they penetrate, control and secure. Their function remains to sustain the artificial entity that is the nation state and ensure that its borders are successfully defended. The decision makers in a state must sustain its geopolitics by retaining and balancing three capabilities : first, the geo-strategy of military defence; second, understand the historical geography of nation and faculitate state cohesion; and, third, engage other states through diplomacy in order maintain alliances and deprive potential and realized enemies of a favourable field of action. This last function still has a an echo with some erstwhile policy makers.John Hillen, the former US Assistant Secretary of State between 2005-07, has argued: there are too many world-views, ideologies, and half-baked assumptions informing the formation of US foreign policy. To this cacophony of preconceived sentiments and assumptions about human nature and utopian fixes to the use of power in the international arena, he offers the following corrective:

The answer should be the map - literally, the physical map, and more broadly, geopolitics classically defined, which of course has political geography at its root. A geopolitical analysis of the United States and the rest of the world offers better guidance for a consistent, smartly managed, prudent, and unapologetic exertion of American power and leadership than any particular political philosophy or perspective on human nature. Of course, the map doesn't spit out easy answers or perfect policies, but geopolitical realities - many of which move as little as the mountains of the Hindu Kush have moved 
in the past several thousand years - can point one in a very sound direction. ${ }^{142}$

\section{Conclusion: Looking Back and Looking Forward}

This chapter has sought to provide an understanding of the scope of geopolitics. It sought to address a fundamental question: ' what is this field of study about'? Despite problems of definition, usage, and the alleged taint of ideology, geopolitics has been redefined and positioned intellectually as a field of study growing out of geography, strategic studies and history. The interdisciplinary relationships between these three academic disciplines that is, geo-strategy, the geography of state formation- inform how geopolitics can be carried forward in a systematic fashion. ${ }^{143}$

The relationships between these three fields do not emerge without paradox. Geo-strategic thinking and action, which emerges out of the juxtaposition of the constraints of geography with the manoeuvres of enemies, are conditioned also by cultural expectations and technological changes, neither of which are static and each of which change according to different temporal dynamics. Geography does not directly condition strategy; instead, it is refracted through prisms of culture and technology. With respect to the geography of state-formation, the most important paradoxical development of the past century is the rise of transnational ethnic groups and the international flow of commodities, finance and migrants- globalization. Even as the state became the unambiguous sovereign over its domain, ethnic minorities and economic developments,

\footnotetext{
${ }^{142}$ J. Hillen, "Foreign Policy by Map: What Geopolitics Is, and Why We Need It," National Review, February 23, 2015, https://www.nationalreview.com/nrd/articles/397926/foreign-policy-map, accessed September 29, 2015.

${ }^{143}$ For a recent example of how geo-strategy and historical geography should be incorporated into explanations of how diplomatic history unfolds, see R. W. Aguirre, The Panama Canal, in International Straits of the World, vol. 15, ed. by Gerard J. Mangone (Boston: Martinus Nijohoff Publishers, 2010).
} 
each with their own geographies, called the state's dominance in international relations into question.

The next chapter will examine the method and theories of geopolitics. Methodological discussions seek to raise the question, "how to." How does geopolitics answer the issues raised by theories that juxtapose geography, strategy and history in international relations? This question is important for two reasons. Geopolitical methods point toward the description of the constellation of forces which exist or existed at a particular time and within a particular geographical context. Geopolitical theories may suggest contemporary and even future significance of the various forces as they play out across specific locations and contexts; they juxtapose the enduring with the ephemeral thereby providing a way of explaining past change and predicting future developments. ${ }^{144}$ An important caveat is that any theory has its limitations: "Although theory is never complete and is always bound to be at least somewhat wrong, it performs several very useful functions when it defines, categorizes, explains, connects and anticipates." Geopolitical political theories need to be applied to relevant case studies for the efficacy of the theories to be evaluated. One result of this intellectual exercise will be a more systematic explanation as to why policy makers were both successful and unsuccessful in bringing about changes in the geographic scope of their policy objectives.

\footnotetext{
${ }^{144}$ Aron has summarised the constituent elements of geopolitical theory: "The theory itself is constructed on the basis of geographical design, by the simultaneous consideration of a constant element (the land-sea, continental-seafaring opposition) and of three variable elements (the technique of movement on land and on sea, the population and resources utilizable in the rivalry of nations, and the extension of the diplomatic field.” To these variable elements, we would add technological factors. R. Aron, Peace and War ,London: Weidenfeld and Nicolson ,1966, p. 192.

${ }^{145}$ H.R. Winton, An Imperfect Jewel: Military Theory and the Military Profession ,School of Advanced Air and Space Studies, Air University, Maxwell Air Force base ,Alabama p4
} 
The case studies will utilise a number of different geographical contexts. They will draw attention to an idiographic perspective which has a focus on differences rather than sameness: "The military effects of actual situations primarily depend on the level of military technology, the characteristics and distribution of military forces, the missions of these forces, and the geographic characteristics of the area involved. Within this matrix, military geography concerns the effects induced by the area and seeks to predict the effects of specific conditions in specific places upon specific military operations." 146 This has a strong echo with respect to one of the puzzles that social science has to address: "Social life is set in a material world and that variations in circumstance and resources, individual and collective, affect what goes on." 147 The aim will be to focus on the differences in the geographical context and go beyond description and relating one fact to another. It will facilitate analysis and explanation. Despite the variations in context, there is a particular similarity across all the case studies; namely strategy thought and action seeks victory, variously defined, in military contests.Thus, in situations where geo-strategic considerations are at play, geography is intimately related to strategic objectives: "The locations and movements selected arise from some overarching design aimed at defeating the enemy. The objective of strategy is to minimize the prospects of resistance by maintaining mobility and the capacity to surprise." ${ }^{\prime 48}$ It is this effort to develop these contrasting, yet elusively comparable, case studies that constitute the main dimension of this book.

\footnotetext{
${ }^{146}$ L.C. Peltier and G.Etzel Pearcy, Military Geography ,New York: Van Nostrand,1966 p167.

${ }^{147}$ M. Hollis, The Philosophy of Social Science, Cambridge: Cambridge University Press ,1994 p202.

${ }^{148}$ P.M. O'Sullivan, The Geography of War in the Post-Cold War World, Ontario: Edwin Mellen Press,2001 p113.
} 
There are five case studies; the first four are historically based. The last one has a contemporary perspective. All five have been selected to demonstrate the effects of the interaction between policy makers and the natural environment. Furthermore, they will show that the outcome of this interaction is not predictable, and the assumption that political outcomes could be explained by focusing exclusively on the material environment as the causal factor is no longer valid. The implications for the three states to be examined: Britain, United States and China will be an ability to evaluate the uniqueness of their approach to the geography with respect to the state they each control and the geographical locations where they attempted to project military and political power. This was conditioned by geography but not determined by it. Other factors such as domestic politics, culture and changes in transport and weapons technology impacted as well.

The first examines one of the episodes in Halford Mackinder's career; his time as British High Commissioner to South Russia during the Russian Revolution. This case study explores two important changes. The first is what Smith called the geopolitical 'shakeout' that occurred after the First World War with the demise of multinational empires. The second addresses how the challenges and the internal domestic influences led eventually to a British Coalition government, led by Lloyd George, to consciously withdraw geo-strategically from South Russia where it had been providing military aid to the White Russian Army and to reduce the geopolitical scope of British foreign policy. This was despite Mackinder presenting the British Cabinet with a plan that advocated geostrategic engagement, albeit on a smaller and more sustainable level.

The second case study focuses on the consequences of erroneous geopolitical assumptions and the abject failure to recognise the geostrategic 
implications of changing geopolitics during World War II. Pivotal to these errors and failures was the development of a transportation and weapons technology revolution encapsulated by the $\mathrm{U}$ boat. The fall of France in 1940 had nearly terminated Britain's sea control and sea denial around the British Isles. Britain soon thereafter attempted to re-establish a favourable geographical field of operations that could sustain operations against the Kreigsmarine in the Battle of the Atlantic. The key aspect of this campaign was the increase geostrategic importance attached to Northern Ireland, a location which enabled a more efficient protection of merchant convoys across the Atlantic. The conduct of these operations based in Northern Ireland led to a revaluation of the geopolitics of the British Isles. When the Irish Free State announced it was leaving the Commonwealth in 1949, a British Cabinet document concluded : "it has become a matter of first-class strategic importance to this country that the north should continue to form part of His Majesty's dominions."

The third case study examines the changing relationship between the geographical scope of US foreign policy and subsequent strategy from the late 1930s through the World War II. Did US policy makers conclude that existing geopolitical and geostrategic conceptions of the role of the United States had become inadequate? America's entry into this conflict raised two questions about the utilization of geopolitics. First, was geopolitics merely used as a tool of propaganda, its function merely to convince the public that the two powerful enemies of December 1941 deserved to be defeated and that a global conflict was justified? Or was geopolitics used to educate the US citizenry, soldiers and policy makers? The need to wage a global war brought about the involvement of professional geographers on an

${ }^{149}$ Ireland: report of working party of officials . $1^{\text {st }}$ January 1949 TNA CAB/29/32. 
unprecedented scale. What was the nature and content of that education? In the final analysis, both policy makers and senior military commanders appreciated the changes that were taking place, changes that suggested the reduced utility of absolute as compared to relative space.

The fourth case study will address the geopolitical challenges that the United States faced in the post-War world. The emergence of a new geopolitical reality on the Eurasian continent, a victorious and expansive Soviet Union, caused the United States to formulate a grand strategy of containment, the scope of which would extend to the whole of the Eurasian rimland and entail an unprecedented peacetime expansion in the scope of U.S. foreign policy.Containment across Eurasia required a new geo-strategy that underlined a new capability to project military power on a global scale that was without precedent. This would reach its apotheosis with perceived threats in a number of geographical locations, each of which was vested with a strategic importance that was not merited in terms of the existing geopolitical realities. In order to escape from these assumptions regarding the unrelenting spread of Communism, President Richard Nixon and Henry Kissinger reappraised the Sino-Soviet split and the US relationship with China as a new way of balancing and containing the power of the Soviet Union.

The last case study addresses the expansion of contemporary China. The realities of Chinese expansion are dissolving the Cold war era geopolitical dichotomy of a Eurasian heartland contained by an alliance of maritime powers situated along the continental rimland. The Chinese state is now constructing a number of 'amphibian ports' that have fused together overland transport via rail, road, and pipeline with intermodal maritime shipping via containerization. The geostrategy implications of these 
developments will be examined in the context of what Darwin has described as a "pattern of persistence." 150 He has argued that with exception of India, European domination of Asia was partial at best; China, on the other hand, endured the high water mark of European imperialism in a manner that is unique: "The idea of China survived both the end of the imperial monarchy in 1911 and the forty years of turmoil, occupation and war that followed soon after. More surprising, perhaps, was China's retention of its huge Inner Asian empire: Manchuria, Mongolia, Sinkiang and Tibet. Despite the desperate crisis of the 1930s and 40's, all were held on to."151 This case study will speculate on, first, whether China is now in the process of uniting the Eurasian Heartland utilizing a different geo-strategy and, second, if the United States and its allies, in the future, will be challenged by a land-power that will bear little resemblance to the challenges that emerged from Eurasia in the twentieth century.

This book addresses three interrelated questions: why does the geographical scope of political objectives and subsequent strategy of states change? How do these changes occur? Over what period of time do these changes occur? Taken together these five case studies offer the prospect of converting descriptions of historical change into analytic explanations, thereby highlighting the importance of a number of commonly overlooked variables. In addition, the case studies will illuminate the challenges that states face when changing the scope of their foreign policy and geo-strategy in response to shifts in geopolitical reality.

\footnotetext{
${ }^{150}$ J. Darwin ,After Tamerlane, London: Penguin Books,2008 p496.

${ }^{151}$ Ibid p496.
} 
